\title{
Possible earthquake trigger for 6th century mass wasting deposit at Lake Ohrid (Macedonia/Albania)
}

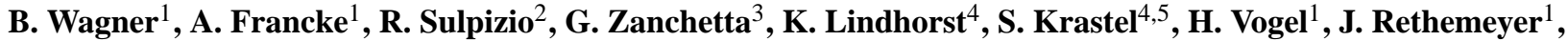 \\ G. Daut ${ }^{6}$, A. Grazhdani ${ }^{7}$, B. Lushaj ${ }^{7}$, and S. Trajanovski ${ }^{8}$ \\ ${ }^{1}$ Institute of Geology and Mineralogy, University of Cologne, Zülpicher Str. 49a, 50674 Cologne, Germany \\ ${ }^{2}$ Dipartimento di Scienze della Terra e Geoambientali, University of Bari, Italy \\ ${ }^{3}$ Dipartimento di Scienze della Terra, University of Pisa, Italy \\ ${ }^{4}$ Helmholtz Centre for Ocean Research, GEOMAR, Kiel, Germany \\ ${ }^{5}$ Institute of Geosciences, University of Kiel, Germany \\ ${ }^{6}$ Institute of Geography, University of Jena, Germany \\ ${ }^{7}$ Institute of Geosciences \& Energy, Water \& Environment, Polytechnic University of Tirana, Albania \\ ${ }^{8}$ Hydrobiological Institute Ohrid, 6000 Ohrid, Macedonia
}

Correspondence to: B. Wagner (wagnerb@uni-koeln.de)

Received: 10 August 2012 - Published in Clim. Past Discuss.: 7 September 2012

Revised: 20 November 2012 - Accepted: 12 December 2012 - Published: 20 December 2012

\begin{abstract}
Lake Ohrid shared by the Republics of Albania and Macedonia is formed by a tectonically active graben within the south Balkans and suggested to be the oldest lake in Europe. Several studies have shown that the lake provides a valuable record of climatic and environmental changes and a distal tephrostratigraphic record of volcanic eruptions from Italy. Fault structures identified in seismic data demonstrate that sediments have also the potential to record tectonic activity in the region. Here, we provide an example of linking seismic and sedimentological information with tectonic activity and historical documents. Historical documents indicate that a major earthquake destroyed the city of Lychnidus (today: city of Ohrid) in the early 6th century AD. Multichannel seismic profiles, parametric sediment echosounder profiles, and a $10.08 \mathrm{~m}$ long sediment record from the western part of the lake indicate a $2 \mathrm{~m}$ thick mass wasting deposit, which is tentatively correlated with this earthquake. The mass wasting deposit is chronologically well constrained, as it directly overlays the AD 472/AD 512 tephra. Moreover, radiocarbon dates and cross correlation with other sediment sequences with similar geochemical characteristics of the Holocene indicate that the mass wasting event took place prior to the onset of the Medieval Warm Period, and is attributed it to one of the known earthquakes in the region in the early 6th century AD.
\end{abstract}

\section{Introduction}

Lake Ohrid $\left(40^{\circ} 54^{\prime}-41^{\circ} 10^{\prime} \mathrm{N}, 20^{\circ} 38^{\prime}-20^{\circ} 48^{\prime} \mathrm{E}\right.$, Fig. 1) is a transboundary lake located on the Balkan Peninsula and shared between the Republics of Macedonia and Albania. The lake is about $30 \mathrm{~km}$ long, $15 \mathrm{~km}$ wide and has an area of $360 \mathrm{~km}^{2}$ (Stankovic, 1960). According to geological and biological age estimations the lake formed about 2-5 Ma ago (summarised in Albrecht and Wilke, 2008). The lake is situated in a tectonically active, $\mathrm{N}-\mathrm{S}$ trending graben (Burchfiel et al., 2008; Hoffmann et al., 2010), which results in a relatively simple bathtub-shaped morphology, with steep slopes along the western and eastern sides and less inclined slopes in the northern and southern part. The average water depth is $150 \mathrm{~m}$ and the maximum water depth is $293 \mathrm{~m}$ (new data from seismic survey). The current lake level is at $693 \mathrm{~m}$ above sea level (a.s.l.) and the lake is surrounded by the Mokra Mountains to the west (1514 m a.s.1.) and the Galicica Mountains to the east (2265 m a.s.l.; Fig. 1).

Several studies on up to ca. $15 \mathrm{~m}$ long sediment sequences have shown that Lake Ohrid is a valuable archive of climatic and environmental changes over the last glacial/interglacial cycle (e.g., Wagner et al., 2009, 2010; Vogel et al., 2010a). Moreover, tephrostratigraphic studies revealed that Lake Ohrid and neighboring Lake Prespa are important distal 


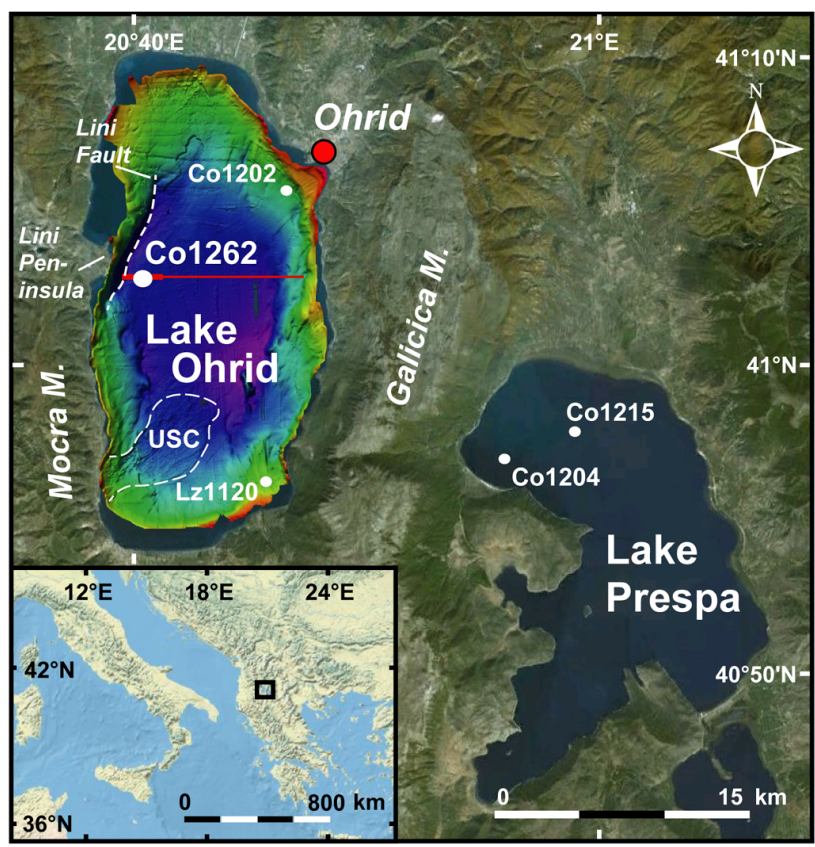

Fig. 1. Map of the northern Mediterranean region showing the location of lakes Ohrid and Prespa. White dots indicate coring locations Lz1120 and Co1202 from field campaigns in 2005 and 2007 in the southeastern and northeastern part of Lake Ohrid, and the new coring location Co1262 in the western part of the lake, as well as coring locations Co1204 and Co1215 from former field campaigns at Lake Prespa (Wagner et al., 2010, 2012). The red line in Lake Ohrid indicates the location of the multichannel seismic (entire line) and hydro-acoustic (thick line) profiles shown in Figs. 2 and 3. White dashed lines in Lake Ohrid indicate the location of the Lini Fault and the Udenisht Slight Complex (USC). The red dot indicates the approximate location of the city of Ohrid.

archives of explosive eruptions from Italian volcanoes (summarised in Sulpizio et al., 2010a; Caron et al., 2010; Vogel et al., 2010b, Damaschke et al., 2012). Hiatuses and disturbed sedimentation in some of the studied sediment sequences from Lake Ohrid can probably be explained by tectonic activity in the region triggering several landslides (e.g., Wagner et al., 2009; Vogel et al., 2010a). These mass wasting deposits and associated fault structures are also recorded in seismic profiles from the lake and occur mainly in the marginal parts of the lake basin (Wagner et al., 2008a; Reicherter et al., 2011). A detailed morphological mapping of the floor of Lake Ohrid by means of an ELAC 1180 Seabeam system revealed that most of the southwestern part of the lake is affected by a large mass failure event, the so-called Udenisht Slide Complex (Fig. 1; Lindhorst et al., 2012). Though some of the mass wasting deposits may be triggered by distinct lake level fluctuations (Lindhorst et al., 2010), most of them likely formed due to tectonic activity (Reicherter et al., 2011). As Lake Ohrid is located within the Korca-Ohrid Earthquake Source Zone, several medium to large earthquakes have occurred within the last $2000 \mathrm{yr}$ (e.g., Aliaj et al., 2004). For example, recent earthquakes occurred on 6 June $2012(M=4.4)$, on 6 September 2009 $(M=5.6)$, and on 23 November 2004 ( $M=5.4)$ (EuropeanMediterranean Seismological Centre, EMSC, 2012). More destructive earthquakes in the younger history are recorded in 1963 close to capital city of Macedonia, Skopje $(M=6.1$, Suhadolc et al., 2004), or in 1911 at Lake Ohrid with a Magnitude of 6.7 (Ambraseys and Jackson, 1990; Mucço et al., 2002). Unfortunately, the database is less well constrained for historical times. According to Aliaj et al. (2004), a major earthquake destroyed the cities of "Lychnidus" (today: city of Ohrid) and "Scupi" (today: city of Skopje), which is located ca. $120 \mathrm{~km}$ towards the northeast of Ohrid, at 518 AD. This data can also be found in most public reports. In contrast, Ambraseys (2009) reports that this earthquake rather affected the city of Scupi, whilst the city of Lychnidus was destroyed $9 \mathrm{yr}$ later at $527 \mathrm{AD}$. This data could correspond with the data indicated in Reicherter et al. (2011, and references therein), according to which the city of Lychnidus was destroyed in late May $526 \mathrm{AD}$, by a magnitude $M>6$ earthquake. Despite these uncertainties, it seems unquestionable that at least one major earthquake affected the Ohrid region in the beginning of the 6th century AD.

Here we combine seismic, sedimentological, climatic, tephrostratigraphic, and historical information in order to trace back the possible signature of 6th century earthquakes on the Lake Ohrid sediment record. In light of the available data, we furthermore evaluate the potential of Lake Ohrid for paleoseismicity investigations, as it was proposed by Reicherter et al. (2011) and demonstrated in other lacustrine (e.g., Schnellmann et al., 2002) or marine basins (e.g., Beck et al., 2012).

\section{Material and methods}

Hydro-acoustic surveys were carried out in Lake Ohrid between 2004 and 2009 in order to obtain information on the lake's bathymetry and sedimentary architecture. Multichannel seismic surveys were carried out in 2007 and 2008 using a Mini GI Gun $(0.25 \mathrm{~L}$ in 2007 and $0.1 \mathrm{~L}$ in 2008) and a 16channel $100 \mathrm{~m}$ long streamer. In addition, a multibeam survey was carried out in 2009 using an ELAC 1180 Seabeam system. These surveys have shown prominent faults and halfgraben structures along the western and eastern margins of the lake, which were also indicated in parametric sediment echosounder profiles (SES-96 light in 2004 and SES 2000 compact in 2007 and 2008, Innomar Co.). In front of the Lini Peninsula at the western margin of the lake (Fig. 1), where a succession of mass wasting deposits was indicated in the multichannel seismic surveys (Reicherter et al., 2011; Fig. 2), also parametric echosounder profiles were obtained. The parametric sediment echosounder transducer was mounted on the side of a small research vessel. The effective frequency 


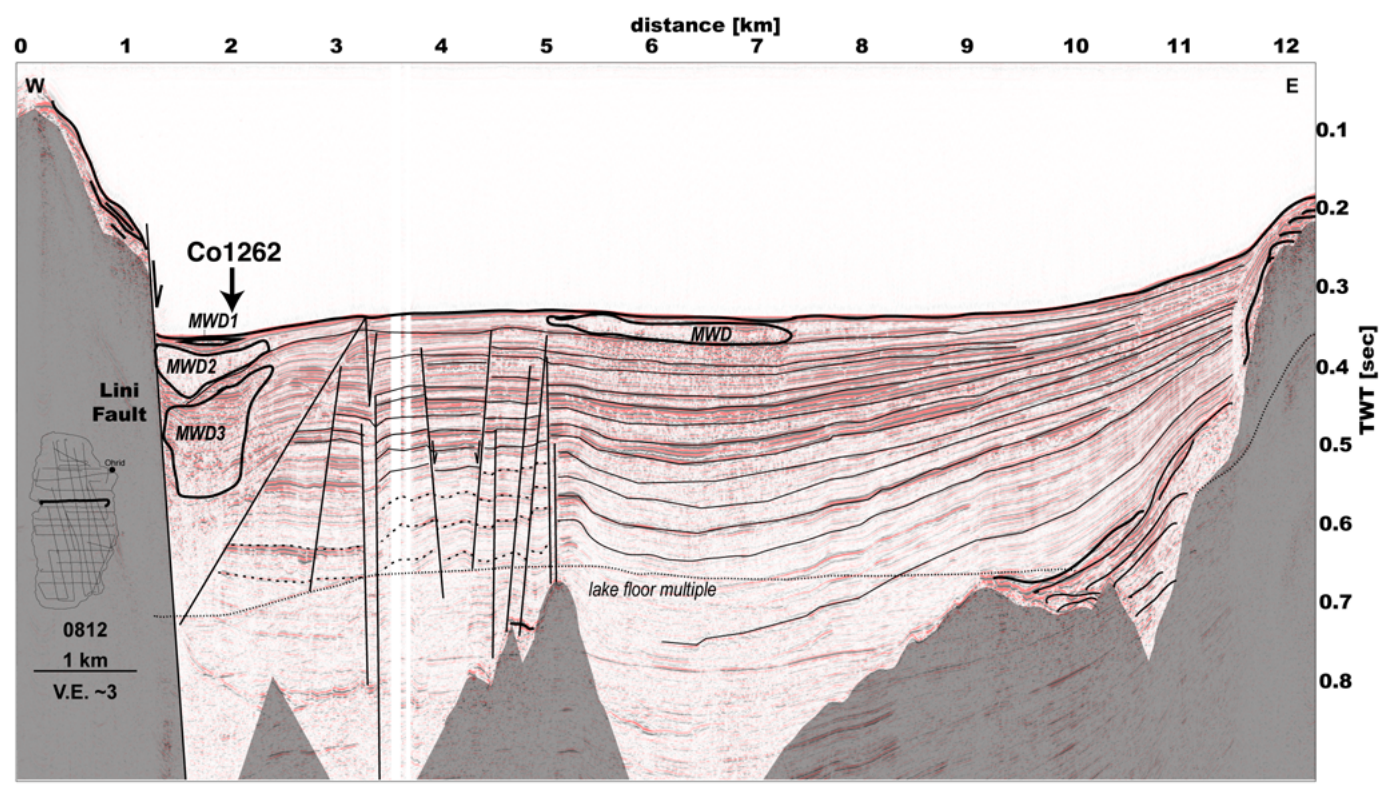

Fig. 2. Interpreted multichannel seismic profile taken by a Mini GI Gun across Lake Ohrid with the Lini Fault in the west. Grey parts indicate bedrock. The arrow indicates coring location Co1262. Transparent sediment bodies indicate mass wasting deposits (MWD1-3).

of the echosounder was set to $10 \mathrm{kHz}$ in order to obtain the optimum settings ranging from deep penetration to high resolution. The sound velocity in the water was set to $1440 \mathrm{~m} \mathrm{~s}^{-1}$. Post-processing was carried out with the INNOMAR software tool ISE 2.9.2. The theoretical vertical resolution of the two types of seismic data can be estimated to ca. $1 \mathrm{~m}$ for the Mini GI gun and $0.2 \mathrm{~m}$ for the Innomar data.

Based on the hydro-acoustic surveys, a coring location in front of the Lini Peninsula $\left(41^{\circ} 03^{\prime} 56.9^{\prime \prime} \mathrm{N}, 020^{\circ} 40^{\prime} 21.9^{\prime \prime} \mathrm{E}\right)$ at $260 \mathrm{~m}$ water depth was selected for the study of mass wasting deposits and their relation to earthquakes. A $10 \mathrm{~m}$ long sediment sequence (Co1262) was recovered in June 2011 from a floating platform using a gravity corer and a $2 \mathrm{~m}$ long percussion piston corer (UWITEC Co. Austria) for deeper sediments. For the recovery of the piston cores, a reentry cone was positioned on the lake floor. Extension rods of $2 \mathrm{~m}$ length controlled the exact release of the piston during the individual continuous coring process. Core recovery was in the order of $100 \%$ including core catcher samples. Core loss or disturbance of sediment between the individual $2 \mathrm{~m}$ segments can therefore be regarded as low $(<6 \mathrm{~cm})$. After recovery, the $2 \mathrm{~m}$ long sediment cores were cut into ca. $1 \mathrm{~m}$ long segments and stored in the dark at $4{ }^{\circ} \mathrm{C}$ until further processing.

In the laboratory at the University of Cologne, the core segments were opened and one core half was described macroscopically and subjected to high-resolution X-ray fluorescence (XRF) scanning. XRF scanning was performed using an ITRAX core scanner (COX Ltd., Sweden), which was equipped with a Cr-tube set to $30 \mathrm{kV}$ and $30 \mathrm{~mA}$, and a Si-drift chamber detector. Core Co1262 was scanned with a resolution of $2 \mathrm{~mm}$ and a scanning time of $10 \mathrm{~s}$ per measurement. $\mathrm{Ca}, \mathrm{K}$, and $\mathrm{Sr}$ were selected of the measured elements, as they are indicators for carbonate precipitation, the input of clastic material, and the occurrence of potential tephras and cryptotephras in sediment sequences from Lake Ohrid (Vogel et al., 2010a, b). Total carbon (TC) and total inorganic carbon (TIC) were determined with a DIMATOC 200 (DIMATEC Co.). Total organic carbon (TOC) was calculated by the difference between TC and TIC.

Tephrostratigraphy, radiocarbon dating, and cross correlation with other sediment cores from lakes Ohrid and Prespa were used to provide a chronological framework for core Co1262. Samples from horizons with peaks in $\mathrm{K}$ and $\mathrm{Sr}$ were selected for tephrostratigraphic work. Volcanic ejecta from these horizons were analysed with respect to their geochemical composition according to previous work on sediment cores from Lake Ohrid (Sulpizio et al., 2010a; Vogel et al., 2010b). Energy-dispersive spectrometry (EDS) of glass shards and micro-pumice fragments was performed using an EDAX-DX micro-analyser mounted on a Philips SEM 515 (operating conditions: $20 \mathrm{kV}$ acceleration voltage, $100 \mathrm{~s}$ live time counting, $200-500 \mathrm{~nm}$ beam diameter, 2100-2400 shots s $^{-1}$, ZAF correction). Details about analytical precision, ZAF correction and inter-laboratory comparison can be found in Sulpizio et al. (2010a, b) and Vogel et al. (2010b). Radiocarbon dating on core Co1262 was carried out by accelerator mass spectrometry (AMS) at the University of Cologne Centre for AMS on five samples of terrestrial plant remains and on one sample of fish remains. Sample pre-treatment and graphitisation was carried out according to Rethemeyer et al. (2013). Other macrofossils were not found in core Co1262 and previous studies have shown that 
bulk organic matter dating on Lake Ohrid sediments provided erroneous ages (Wagner et al., 2008a; Vogel et al., 2010a). CALIB 6.1.1 (Stuiver and Reimer, 1993) and the IntCal09 dataset (Reimer et al., 2009) were used for conversion of the conventional radiocarbon ages into calendar ages (cal yr BP) on an uncertainty level of $2 \sigma$. Cross correlation with other sediment cores from lakes Ohrid and Prespa concentrated on carbonate content (TIC and Ca; Lake Ohrid) and organic matter content (TOC; Lake Prespa), as former studies have shown that these proxies sensitively recorded climatic and environmental changes during the Holocene (Wagner et al., 2009, 2010; Vogel et al., 2010a; Aufgebauer et al., 2012). Significant fluctuations in these proxies could have been attributed to significant events, such as the 8.2 cooling event, the Medieval Warm Period (MWP) or Little Ice Age (LIA) and were constrained by tephrostratigraphy and radiocarbon dating on macrofossil remains. Similar fluctuations in core Co1262 are assumed to represent the same events.

\section{Results}

\subsection{Hydro-acoustic survey}

The multichannel seismic survey revealed a succession of three mass wasting events in front of the Lini Peninsula (Fig. 2), where one of the most active faults of the Lake Ohrid graben system is located (cf. Reicherter et al., 2011). The topmost two mass wasting events (MWD1 and MWD2, Fig. 2) are also imaged in the parametric sediment echosounder profile perpendicular to the Lini Peninsula as transparent and partly chaotic seismic units (Fig. 3). Whilst the thickness of MWD2 exceeds $10 \mathrm{~m}$ (Fig. 2), the parametric sediment echosounder profile indicates that the thickness of MWD1 is about $2 \mathrm{~m}$ at the coring location Co1262 (Fig. 3). Between MWD2 and MWD1 and on top of MWD1, parallel to subparallel continuous reflections with low to medium amplitudes indicate widely undisturbed well-stratified sediments. A significant erosional unconformity at the base of MWD1 cannot be detected in the parametric sediment echosounder line at the coring location, probably because MWD1 pinches out only a few hundred meters to the east of the coring location and a potential erosion decreased with increasing distance from the steep slope (Fig. 3).

\subsection{Sediment core}

The geochemical characteristics of the $1008 \mathrm{~cm}$ long sediment sequence Co1262 correlate well with the parametric sediment echosounder data and with sediment cores previously recovered from Lake Ohrid. Overall, core Co1262 is mainly formed by relatively homogenous clayey to silty mud of greyish to olive colour. The sediments appear massive, probably as a result of bioturbation, as it was also observed in other sediment sequences from Lake Ohrid at least throughout the Holocene (Wagner et al., 2009; Vogel et al., 2010a).
Some weak colour changes are probably due to distinct changes in the content of carbonate, which is represented by TIC and $\mathrm{Ca}$, and organic matter, which is represented by TOC (Fig. 4). Significant changes in these constituents were also recorded in other sediment sequences from Lake Ohrid throughout the Holocene (Wagner et al., 2009; Vogel et al., 2010a). The lowermost meter of core Co1262 contains some gravel grains, which were interpreted as ice-rafted debris in other cores from lakes Ohrid and Prespa (Wagner et al., 2009; Vogel et al., 2010a; Aufgebauer et al., 2012). Some changes in grain size composition are correlated with minima in water content and likely represent mass wasting deposits. For example, a $15 \mathrm{~cm}$ thick horizon between 980 and $965 \mathrm{~cm}$ has low, but increasing water content and a fining upward trend in grain size composition from fine sand at its base to fine silt and clay at the top. This is interpreted as a distal turbidite of a mass wasting deposit (Schnellmann et al., 2005). Smaller mass wasting deposits are also indicated at depths of 548 and $350 \mathrm{~cm}$, but they are $<4 \mathrm{~cm}$ thick and too small to be visible in the seismic data. A significant change of the sedimentological and geochemical characteristics occurs at $320 \mathrm{~cm}$ depth, where a $1-2 \mathrm{~cm}$ thick sandy horizon overlays a thin greyish band of $1 \mathrm{~mm}$ thickness (Fig. 5). On top of this sand layer, the sediment is very homogenous until $121 \mathrm{~cm}$ depth. Significant changes in carbonate or organic matter content do not occur and the water content is low, but increases slightly upwards. This homogenous horizon between 320 and $121 \mathrm{~cm}$ depth corresponds with MWD1 in the parametric sediment echosounder data. An erosional discordance at the basis of MWD1 is not distinct in the sediment core (Fig. 5) and matches with the parametric sediment echosounder data. The uppermost $121 \mathrm{~cm}$ of core Co1262 are characterised by silty to clayey mud of greyish to olive colour, relatively high water content, and some distinct fluctuations of TIC and TOC, and likely represent undisturbed pelagic sedimentation.

\section{Chronology of core Co1262 and the mass wasting deposit}

The occurrence of three well-dated tephras, six radiocarbon ages, and the significant patterns of TIC and Ca allow good chronological control of the entire core and, specifically, of MWD1 between 320 and $121 \mathrm{~cm}$ depth.

Overall, the occurrence of ice-rafted debris, low $\mathrm{Ca}$ and TIC at the core base imply that the core reaches back into the Late Pleistocene, when carbonate precipitation in Lake Ohrid was restricted or carbonates were not preserved and when the lake was at least partly ice covered during winter (Wagner et al., 2009; Vogel et al., 2010a). In several studied cores from lakes Ohrid and Prespa, the onset of carbonate precipitation and preservation was correlated with the Pleistocene/Holocene transition (Wagner et al., 2009, 2010; Vogel et al., 2010a; Aufgebauer et al., 2012). However, 


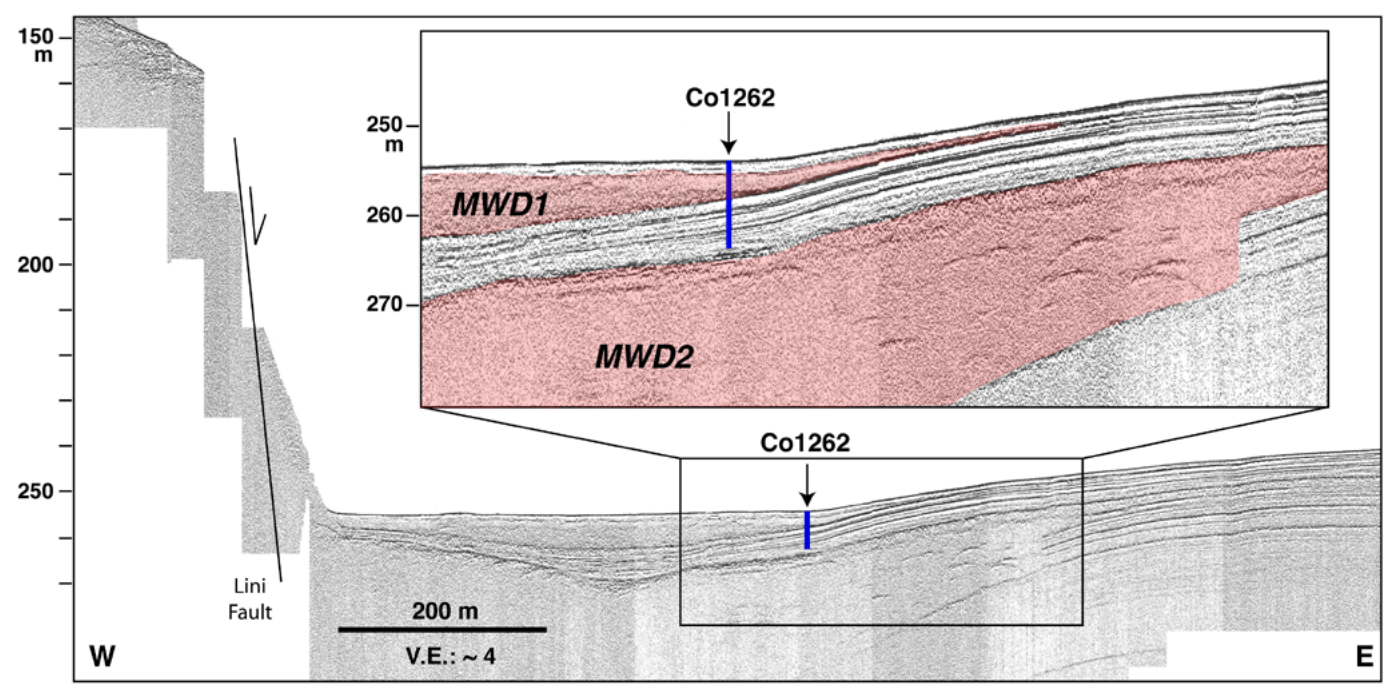

Fig. 3. Uninterpreted and interpreted (insert) hydro-acoustic profile in front of the Lini peninsula (see Fig. 1 for exact location). The profile was obtained with an Innomar transducer. The blue bar indicates the coring location Co1262 and transparent sediment bodies (red coloured in the interpreted insert) indicate mass wasting deposits (MWD1 and MWD2).

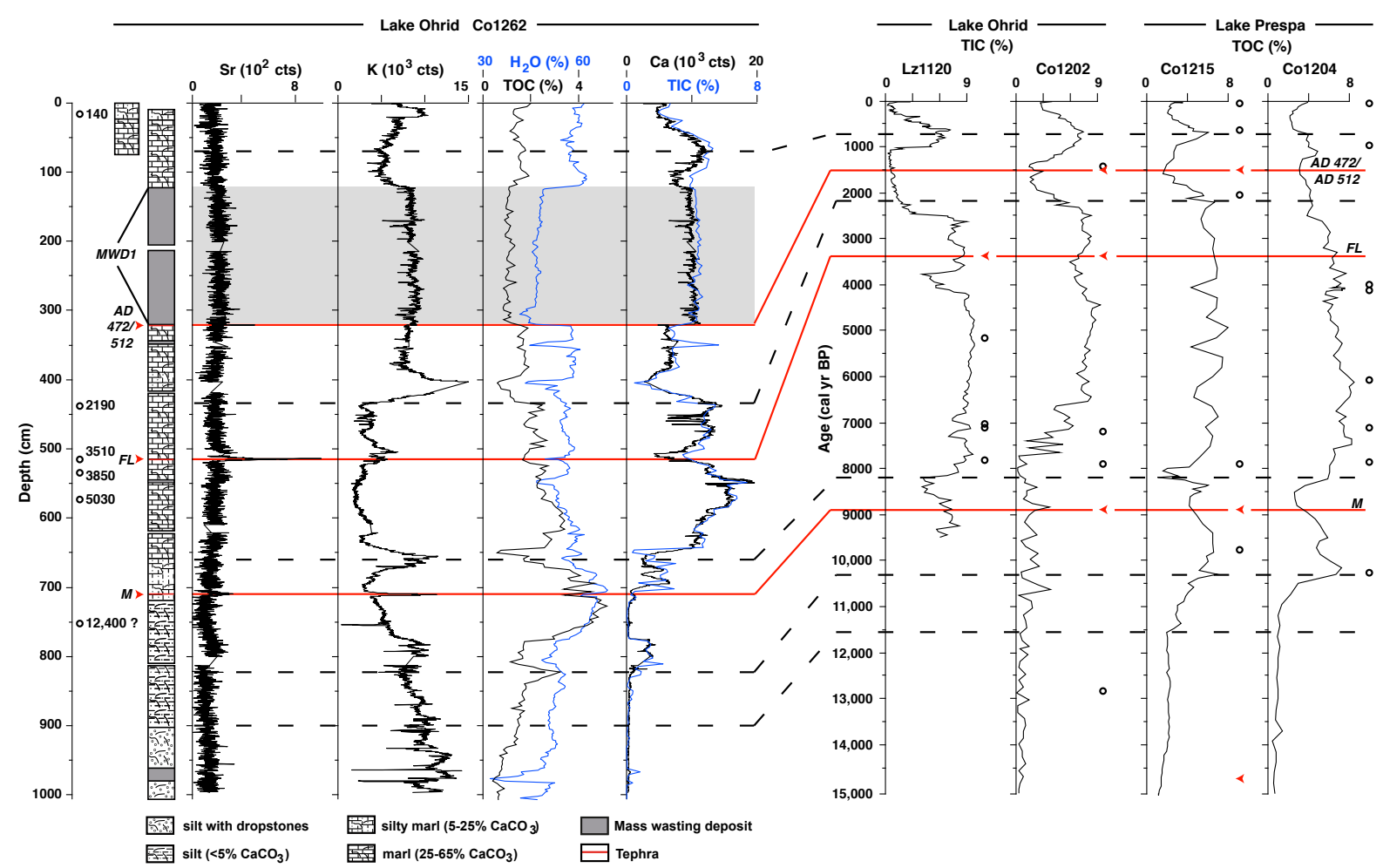

Fig. 4. Lithology, water content, and geochemical composition of core Co1262 from Lake Ohrid. Note that the entire sediment succession appears massive due to bioturbation. The gaps in XRF scanning data ( $\mathrm{Sr}$, K, and Ca counts) are due to non-overlapping cores. These gaps are smaller in water content, TIC, and TOC, as core catcher samples are included. The cross correlation with cores Lz1120 and Co1202 from Lake Ohrid and cores Co1215 and Co1204 from Lake Prespa (black dashed lines) can be used for an age estimation of core Co1262. Red arrows and lines indicate tephras and cryptotephras (AD 472/512, FL eruption, and $\mathrm{M}=$ Mercato). Black circles indicate radiocarbon dated horizons in cores from lakes Ohrid and Prespa (ages in core Co1262 are calibrated ages from Table 1). 
Table 1. Radiocarbon and calendar ages from core Co1262. The calibration of radiocarbon ages into calendar ages is based on Calib 6.1.1 (Stuiver and Reimer, 1993) and INTCAL09 (Reimer et al., 2009) and on a $2 \sigma$ uncertainty.

\begin{tabular}{lrlrll}
\hline AMS Lab ID & $\begin{array}{r}\text { Core depth } \\
(\mathrm{cm})\end{array}$ & Material & $\begin{array}{r}\text { C weight } \\
(\mathrm{mg})\end{array}$ & $\begin{array}{l}{ }^{14} \mathrm{C} \text { age } \\
(\mathrm{yr} \text { BP })\end{array}$ & $\begin{array}{l}\text { Calendar age } \\
(\text { cal yr BP })\end{array}$ \\
\hline COL 1251.1.1 & 17 & terrestrial plant & 1.00 & $164 \pm 20$ & $140 \pm 145$ \\
COL 1735.1.1 & 442 & terrestrial plant & 0.74 & $2176 \pm 46$ & $2190 \pm 140$ \\
COL 1736.1.1 & 520 & terrestrial plant & 0.99 & $3280 \pm 45$ & $3510 \pm 110$ \\
COL 1737.1.1 & 537 & terrestrial plant & 0.93 & $3581 \pm 40$ & $3850 \pm 130$ \\
COL 1738.1.1 & 574 & terrestrial plant & 1.00 & $4370 \pm 44$ & $5030 \pm 190$ \\
COL 1243.1.1 & 754 & fish bone & 0.53 & $10,492 \pm 37$ & $12400 \pm 190$ \\
\hline
\end{tabular}

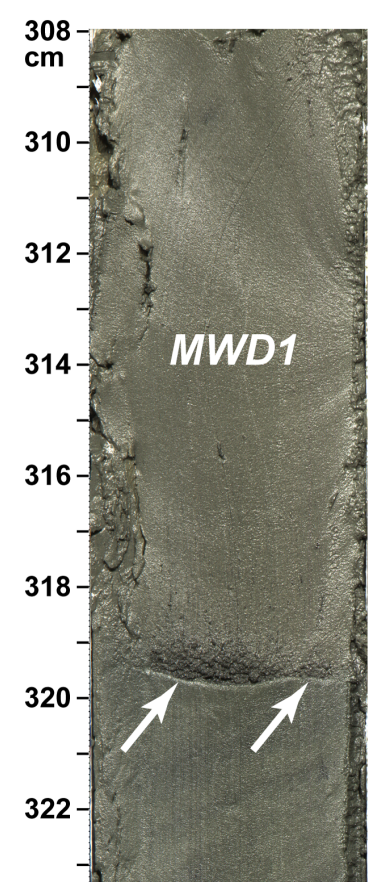

Fig. 5. Photography of the core Co1262, from ca. 308 to $323 \mathrm{~cm}$ depth, where the AD 472/512 tephra as thin, greyish band (arrow) underlies mass waste deposit MWD1 with a sandy base.

most of the existing records from Lake Ohrid apparently are disturbed at the Pleistocene/Holocene transition. In a record from nearby Lake Prespa, a first significant increase of organic matter occurred at the end of the Younger Dryas and the onset of the Holocene (Fig. 4). We assume that the increase of TOC between ca. 950 and $900 \mathrm{~cm}$ and the end of ice-rafted debris deposition at ca. $900 \mathrm{~cm}$ in core Co1262 can also be correlated with the onset of the Holocene. The peaks in TIC and $\mathrm{Ca}$ and the minimum in TOC around $800 \mathrm{~cm}$ depth in core Co1262 could correspond with the period $10500-9500$ cal yr BP, when similar fluctuations are observed at Lake Prespa (Fig. 4; Aufgebauer et al., 2012) and when a minimum in winter precipitation is reconstructed from a record at nearby Lake Maliq (Bordon et al., 2009). The radiocarbon age of the fish remains at $758 \mathrm{~cm}$ indicating a much older age (Table 1). Since reservoir effects of $1500 \mathrm{yr}$ have been measured in several cores from Lake Ohrid (Wagner et al., 2008a; Vogel et al., 2010a), we can also assume that the fish remains are affected by a reservoir effect or that they are re-deposited. The first reliable chronological tie point is given by the peaks in $\mathrm{K}$ and $\mathrm{Sr}$ at $709 \mathrm{~cm}$, which can be attributed to a significant occurrence of glass shards. The geochemical composition of the glass shards suggest that they originate from the Mercato eruption (Table 2, Fig. 6; cf. Damaschke et al., 2012), which has proposed maximum ages of 8890 cal yr BP (Santacroce et al., 2008) and recently dated (using charcoal from the base of the fallout deposits) at $8540 \mathrm{cal}$ yr BP (Zanchetta et al., 2011). The minima in TIC and $\mathrm{Ca}$ and the maximum in $\mathrm{K}$ at $\mathrm{ca} .660 \mathrm{~cm}$ depth are likely correlated with the $8.2 \mathrm{ka}$ cooling event, as observed in other cores from lakes Ohrid and Prespa (Wagner et al., 2009, 2010; Vogel et al., 2010a; Aufgebauer et al., 2012). High TIC and Ca characterise the period after the $8.2 \mathrm{ka}$ cooling event and are explained by warmer temperatures, higher carbonate precipitation and better carbonate preservation (Wagner et al., 2009, 2010; Vogel et al., 2010a; Aufgebauer et al., 2012). The mid-Holocene is chronologically well constrained by three radiocarbon ages between 574 and $514 \mathrm{~cm}$ depth, with ages between 5030 and $3510 \mathrm{cal}$ yr BP (Table 1), and by the occurrence of the FL tephra at $517 \mathrm{~cm}$ depth with an age of $3370 \pm 70$ cal yr BP (Table 2, Figs. 4 and 6; Coltelli et al., 2000; Wagner et al., 2008a). The existing records indicate a second cooling/drying event around $4000 \mathrm{cal}$ yr BP, however, this event is only poorly resolved in core Co1262. A significant decrease of TIC and Ca around ca. 2500 cal yr BP was observed in other cores from Lake Ohrid (Fig. 4), when an anthropogenic impact led to higher erosion in the catchment and increased the clastic matter input into Lake Ohrid (cf. Wagner et al., 2009, 2010; Vogel et al., 2010a). A similar pattern can be observed in core Co1262 at ca. $440 \mathrm{~cm}$ depth, where a terrestrial macrofossil remain yielded an age of $2190 \mathrm{cal} \mathrm{yr} \mathrm{BP}$ (Table 1). Another independent chronological tie point comes from a tephra layer that appears as a thin greyish band just below MWD1 and corresponds to a Sr peak (Figs. 4 and 5). Geochemical identification of volcanic material from this horizon attributes the 
Table 2. Major element glass composition of tephras and cryptotephras in core Co1262.

\begin{tabular}{|c|c|c|c|c|c|c|c|c|c|c|c|c|c|c|}
\hline $\begin{array}{l}\text { Tephra/Crypto- } \\
\text { tephra }\end{array}$ & Shards & $\mathrm{SiO}_{2}$ & $\mathrm{TiO}_{2}$ & $\mathrm{Al}_{2} \mathrm{O}_{3}$ & $\mathrm{FeO}_{\text {tot }}$ & $\mathrm{MnO}$ & $\mathrm{MgO}$ & $\mathrm{CaO}$ & $\mathrm{Na}_{2} \mathrm{O}$ & $\mathrm{K}_{2} \mathrm{O}$ & $\mathrm{P}_{2} \mathrm{O}_{5}$ & $\mathrm{ClO}$ & $\begin{array}{r}\text { Tot. } \\
\text { Alkali }\end{array}$ & $\begin{array}{r}\text { Alk. } \\
\text { Ratio }\end{array}$ \\
\hline \multirow{10}{*}{$\begin{array}{l}\text { Co1262-320 } \\
(\text { AD4்72/512) }\end{array}$} & 1 & 47.77 & 1.14 & 19.35 & 7.96 & 0.12 & 2.5 & 10.39 & 4.95 & 4.94 & 0 & 0.88 & 9.89 & 1.00 \\
\hline & 2 & 48.04 & 1.13 & 20.2 & 7.72 & 0.38 & 1.44 & 8.19 & 6.39 & 5.42 & 0 & 1.1 & 11.81 & 0.85 \\
\hline & 3 & 50.52 & 0.55 & 21.72 & 5.05 & 0.07 & 0.82 & 5.16 & 6.51 & 8.86 & 0 & 0.75 & 15.37 & 1.36 \\
\hline & 4 & 50.49 & 0.7 & 21.77 & 5.22 & 0.13 & 0.99 & 5.96 & 4.81 & 9.19 & 0 & 0.75 & 14.00 & 1.91 \\
\hline & 5 & 54.91 & 1.58 & 18.28 & 7.4 & 0.15 & 2.49 & 5.95 & 5.08 & 3.37 & 0.44 & 0.34 & 8.45 & 0.66 \\
\hline & 6 & 47.72 & 1.02 & 20.36 & 7.75 & 0.14 & 2.35 & 9.81 & 5.94 & 3.99 & 0.15 & 0.77 & 9.93 & 0.67 \\
\hline & 7 & 48.58 & 0.81 & 21.25 & 6.6 & 0.34 & 1.2 & 6.38 & 7.9 & 5.35 & 0.2 & 1.38 & 13.25 & 0.68 \\
\hline & 8 & 48.48 & 0.8 & 20.91 & 7.33 & 0.17 & 1.19 & 7.72 & 6.48 & 5.68 & 0.09 & 1.16 & 12.16 & 0.88 \\
\hline & 9 & 48.88 & 0.77 & 20.17 & 7.76 & 0.19 & 1.81 & 8.56 & 5.69 & 5.22 & 0 & 0.96 & 10.91 & 0.92 \\
\hline & 10 & 48.06 & 1 & 20.87 & 7.08 & 0.42 & 1.4 & 7.76 & 6.91 & 5.43 & 0.07 & 0.99 & 12.34 & 0.79 \\
\hline \multirow{11}{*}{$\begin{array}{l}\text { Co1262-517 } \\
\text { (FL) }\end{array}$} & 1 & 51.87 & 1.94 & 17.78 & 9.86 & 0.15 & 2.69 & 4.89 & 6.01 & 3.77 & 0.67 & 0.36 & 9.78 & 0.63 \\
\hline & 2 & 53.84 & 1.78 & 19.37 & 7.47 & 0.24 & 1.85 & 4.6 & 6.77 & 3.42 & 0.37 & 0.29 & 10.19 & 0.51 \\
\hline & 3 & 54.4 & 1.72 & 18.7 & 6.42 & 0.15 & 2.38 & 4.97 & 5.69 & 4.58 & 0.59 & 0.4 & 10.27 & 0.80 \\
\hline & 4 & 53.96 & 1.89 & 17.41 & 8.18 & 0.23 & 2.83 & 5.45 & 5.58 & 3.62 & 0.46 & 0.38 & 9.2 & 0.65 \\
\hline & 5 & 53.4 & 1.82 & 17.69 & 8.53 & 0.24 & 3.07 & 4.97 & 5.46 & 4.01 & 0.52 & 0.29 & 9.47 & 0.73 \\
\hline & 6 & 55.25 & 1.8 & 18.1 & 7.31 & 0.33 & 2.23 & 4.36 & 6.03 & 3.91 & 0.39 & 0.28 & 9.94 & 0.65 \\
\hline & 7 & 53.93 & 1.44 & 18.44 & 7.81 & 0 & 3.4 & 6.36 & 5.28 & 2.86 & 0.31 & 0.17 & 8.14 & 0.54 \\
\hline & 8 & 53.87 & 1.5 & 17.87 & 7.94 & 0 & 3.48 & 6.24 & 5.54 & 3.01 & 0.35 & 0.2 & 8.55 & 0.54 \\
\hline & 9 & 54.01 & 1.91 & 17.46 & 8.17 & 0.3 & 2.75 & 5.55 & 5.4 & 3.68 & 0.45 & 0.31 & 9.08 & 0.68 \\
\hline & 10 & 53.36 & 1.74 & 18.26 & 7.62 & 0.27 & 3.37 & 5.82 & 5.73 & 3.15 & 0.35 & 0.33 & 8.88 & 0.55 \\
\hline & 11 & 54.15 & 1.54 & 18.71 & 7.71 & 0.1 & 3.26 & 5.79 & 5.01 & 3.15 & 0.35 & 0.22 & 8.16 & 0.63 \\
\hline \multirow{12}{*}{$\begin{array}{l}\text { Co1262-709 } \\
\text { (Mercato) }\end{array}$} & 1 & 51.87 & 1.94 & 17.78 & 9.86 & 0.15 & 2.69 & 4.89 & 6.01 & 3.77 & 0.67 & 0.36 & 9.78 & 0.63 \\
\hline & 2 & 53.84 & 1.78 & 19.37 & 7.47 & 0.24 & 1.85 & 4.6 & 6.77 & 3.42 & 0.37 & 0.29 & 10.19 & 0.51 \\
\hline & 3 & 54.4 & 1.72 & 18.7 & 6.42 & 0.15 & 2.38 & 4.97 & 5.69 & 4.58 & 0.59 & 0.4 & 10.27 & 0.80 \\
\hline & 4 & 53.96 & 1.89 & 17.41 & 8.18 & 0.23 & 2.83 & 5.45 & 5.58 & 3.62 & 0.46 & 0.38 & 9.2 & 0.65 \\
\hline & 5 & 53.4 & 1.82 & 17.69 & 8.53 & 0.24 & 3.07 & 4.97 & 5.46 & 4.01 & 0.52 & 0.29 & 9.47 & 0.73 \\
\hline & 6 & 55.25 & 1.8 & 18.1 & 7.31 & 0.33 & 2.23 & 4.36 & 6.03 & 3.91 & 0.39 & 0.28 & 9.94 & 0.65 \\
\hline & 7 & 53.93 & 1.44 & 18.44 & 7.81 & 0 & 3.4 & 6.36 & 5.28 & 2.86 & 0.31 & 0.17 & 8.14 & 0.54 \\
\hline & 8 & 53.87 & 1.5 & 17.87 & 7.94 & 0 & 3.48 & 6.24 & 5.54 & 3.01 & 0.35 & 0.2 & 8.55 & 0.54 \\
\hline & 9 & 54.01 & 1.91 & 17.46 & 8.17 & 0.3 & 2.75 & 5.55 & 5.4 & 3.68 & 0.45 & 0.31 & 9.08 & 0.68 \\
\hline & 10 & 53.36 & 1.74 & 18.26 & 7.62 & 0.27 & 3.37 & 5.82 & 5.73 & 3.15 & 0.35 & 0.33 & 8.88 & 0.55 \\
\hline & 11 & 54.15 & 1.54 & 18.71 & 7.71 & 0.1 & 3.26 & 5.79 & 5.01 & 3.15 & 0.35 & 0.22 & 8.16 & 0.63 \\
\hline & 12 & 54.15 & 1.54 & 18.71 & 7.71 & 0.1 & 3.26 & 5.79 & 5.01 & 3.15 & 0.35 & 0.22 & 8.16 & 0.63 \\
\hline
\end{tabular}

tephra to the AD 472/512 eruption of the Somma-Vesuvius (Table 2, Fig. 6; Wagner et al., 2008b; Sulpizio et al., 2010a; Vogel et al., 2010b). The geochemical differentiation between the AD 472 and AD 512 tephras is relatively easy, if the entire succession of the AD 472 eruption is preserved, because the composition of tephras from this event straddles the fields of phonolite, foidites and tephra-phonolites (Fig. 6; Santacroce et al., 2008). It becomes more difficult if only the final products of the AD 472 eruption are recognized, because they have a large compositional overlap with the AD 512 tephra (Sulpizio et al., 2010a, b). Volcanic ejecta from the AD 472 eruption were clearly identified in Lake Shkodra (Sulpizio et al., 2010b; Zanchetta et al., 2012), which is located ca. $160 \mathrm{~km}$ northwest of Lake Ohrid. In formerly studied cores from lakes Ohrid and Prespa, however, a mixture of AD 472 and AD 512 tephras was proposed (Vogel et al., 2010b; Damaschke et al., 2012). As the geochemical composition of the tephra at $320 \mathrm{~cm}$ depth in core Co1262 is similar to those previously found in lakes Ohrid and Prespa, we assume that it also includes the AD 512 deposits. The sandy horizon at the base of MWD1 is deposited directly above the AD 472/512 tephra. Calculating a mean sedimentation rate of ca. $1 \mathrm{~mm} \mathrm{yr}^{-1}$ between the carbonate decline at ca. $440 \mathrm{~cm}$ depth (2200 cal yr BP) and the occurrence of the AD 472/512 tephra (1478/1438 cal yr BP) at $320 \mathrm{~cm}$ depth, we can assume that the mass movement occurred less than $20 \mathrm{yr}$ after the deposition of the AD 472/512 tephra. Potential triggers for a mass movement include delta collapses, rockfalls, lake level changes, or earthquakes (e.g., Schnellmann et al., 2006; Girardclos et al., 2007). A delta collapse can be excluded, as there is no inlet close to the coring location and deltaic deposits cannot be observed in the seismic data (Figs. 2 and 3). The steep subaquatic slopes close to the Lini Peninsula could have promoted rockfalls, but typical rockfall structures, such as relatively fresh scarps onshore or subaquatic basin-marginal cones cannot be observed (cf. 


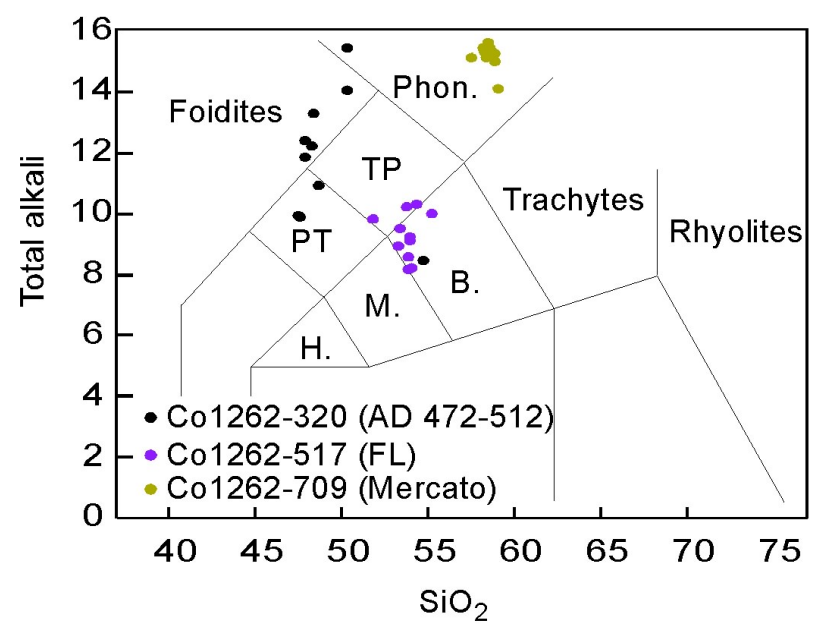

Fig. 6. Classification of tephras and cryptotephras recognised in core Co1262 from Lake Ohrid by means of the total alkali vs. silica diagram (TAS, Le Bas et al., 1986). The raw data of tephras and cryptotephras is given in Table 1.

Schnellmann et al., 2006; Figs. 1 and 2). The existing records from lakes Ohrid and Prespa or paleoclimatic reconstructions from the region do not indicate that the early 6th century $\mathrm{AD}$ was characterised by significant changes in lake level and hydrology (e.g., Wagner et al. 2009, 2010, 2012; Lindhorst et al., 2010; Vogel et al., 2010a; Leng et al., 2012). However, historical documents indicate that an earthquake destroyed the city of Lychnidus (Ohrid) in the early 6th century AD. Potential candidates for such an earthquake are the $518 \mathrm{AD}$ earthquake, which according to some authors more affected the city of Scupi (Skopje; Aliaj et al., 2004; Ambraseys, 2009), or the 526 or $527 \mathrm{AD}$ earthquake, which concentrated more on the Ohrid region (Ambrasyes, 2009; Reicherter et al., 2011). Although the bioturbated structure of the sediment core and the impossible differentiation between the AD 472 and AD 512 tephra do not allow a chronological discrimination between the two (or three) earthquakes, it is evident that MWD1 must have occurred during the early 6th century AD and is likely related to one of these earthquakes. An early 6th century AD age of MWD1 is confirmed by the patterns of TIC and $\mathrm{Ca}$ on top of it, which are again similar to those of former cores from Lake Ohrid. After low Ca between 121 and $100 \mathrm{~cm}$ depth, which would correspond to a period of ca. $200 \mathrm{yr}$ based on a sedimentation rate of ca. $1 \mathrm{~mm} \mathrm{yr}^{-1}$, the increase of $\mathrm{Ca}$ and TIC can be correlated with the onset of the MWP, which culminated at 900-1000 AD in other cores from lakes Ohrid and Prespa (summarised in Wagner et al., 2010 and Aufgebauer et al., 2012; Fig. 4) and between 1000 and $1200 \mathrm{AD}$ in the eastern Mediterranean (Kaniewski et al., 2011). The subsequent minimum of $\mathrm{Ca}$ and TIC correlates with the LIA (Wagner et al., 2009, 2010; Vogel et al., 2010a), and is confirmed by the age of macrofossil remains at $17 \mathrm{~cm}$ depth ( $140 \mathrm{cal} \mathrm{yr} \mathrm{BP,} \mathrm{Table} 1)$. Recent warming led to increasing $\mathrm{Ca}$ and TIC at the sediment surface.

\section{Comparison with other sites}

According to the chronological tie points and the patterns of geochemical fluctuations the Holocene sedimentation rates at the Lini site Co1262 are varying distinctly (Fig. 4) and are relatively high compared with other sites from the lake. After subtracting the mass wasting deposits in core Co1262, the Holocene sediments comprise almost $8 \mathrm{~m}$, which is about twice as much as the Holocene sediment succession in the northeastern part of the lake (core Co1202, Fig. 1, Vogel et al., 2010a). In the southeastern part of the lake, the thickness of the Holocene sediment succession was similar (core Lz1120, Fig. 1, Wagner et al., 2009), but this coring location is close to an inlet. There is no significant inlet close to the site Co1262 and Lake Ohrid is an oligotrophic lake with relatively simple basin morphology. The significant variations in sedimentation rates and the overall high sedimentation rate suggest lake internal currents (Vogel et al., 2010c) and/or contourite drift as observed in Lake Prespa (Wagner et al., 2012) or other lakes (e.g., Girardclos et al., 2003; Gilli et al., 2005). Another reason for the varying but high sedimentation is probably due to the tectonic activity along the western margin of the lake. According to seismic data, the region around Lini Fault, which is one of the oldest faults in Lake Ohrid Basin, located offshore of Lini Peninsula is one of the most active areas. Half-grabens were developed within the hanging wall of related fault structures, creating depocentres that are filled with re-deposited material from the footwall. Seismic activity probably also induced the Udenisht Slide in the southwestern part of the lake (Fig. 1; Lindhorst et al., 2012). The chronological control of this slide is poor, but extrapolation of sedimentation rates of overlying sediment indicates that this slide is younger than $1500 \mathrm{yr}$ and also probably associated with an early 6th century AD earthquake (Lindhorst et al., 2012). These observations strongly suggest that major earthquakes in Lake Ohrid triggered lacustrine slides and are confirmed by onshore information, which indicate that the morphology of the Ohrid basin is formed by frequent earthquakes of magnitudes between $M 6.0$ and 7.0 (Reicherter et al., 2011). Hence age estimation of these mass wasting deposits can be used as a proxy for estimating paleoseismicity. For example, the thick mass wasting deposit MWD2, which underlies core sequence Co1262, could originate from an older, Late Pleistocene earthquake. Most existing sediment records from Lake Ohrid spanning into the last glacial cycle have disturbed sedimentation at the Late Pleistocene/Holocene transition (Wagner et al., 2009; Vogel et al., 2010a), which might be related to high seismic activity. There are a number of other slides indicated in multichannel seismic sections Lindhorst et al. (2012), which suggest that a long paleoseismic record will become available once a deep drill core will be recovered from Lake Ohrid. 


\section{Conclusions}

The Co1262 record shows the high potential of Lake Ohrid for paleoseismicity investigations, by combining seismic, sedimentological, climatic, tephrostratigraphic, and historical information. The most significant mass wasting deposit in core Co1262 is ca. $2 \mathrm{~m}$ thick and overlays a tephra, which is correlated with the AD 472/512 eruption of the SommaVesuvius. The exact age of the mass wasting deposit cannot be defined, because there is a geochemical overlap of the AD 472 and the AD 512 tephra and the sediments of Lake Ohrid are not annually laminated. However, the lack of apparent erosional discordance at the base of the mass wasting deposit and the small distance to the AD 472/512 tephra imply that the mass wasting deposit occurred in the early 6th century AD. This age is confirmed by the sediments, which overlay the mass wasting deposit and show characteristic variations related to the Medieval Warm Period and the Little Ice Age. Several potential triggers for this mass wasting event, such as delta collapses, rockfalls, or lake level changes can be excluded or are unlikely. More likely is a correlation with a historical earthquake, which destroyed the city of Lychnidus (Ohrid) in the early 6th century AD. According to historical documents, this earthquake could have occurred at $518 \mathrm{AD}, 526 \mathrm{AD}$, or $527 \mathrm{AD}$. Within the framework of such uncertainties, core Co1262 is a very nice example of Holocene paleoseismicity studies. More data from other locations of the lake and similar examples from older periods will be needed to shed more light on the earthquake history of the lake.

Acknowledgements. The study was funded by the German Research Foundation (WA 2109/11) and by the International Continental Scientific Drilling Program (ICDP).

Edited by: K. Reicherter

\section{References}

Albrecht, C. and Wilke, T.: Ancient Lake Ohrid: biodiversity and evolution, Hydrobiology, 615, 103-140, 2008.

Aliaj, S., Adams, J., Halchuk, S., Sulstarova, E., Peci, V., and Muco, B.: Probabilistic Seismic Hazard Maps for Albania, 13th World Conference on Earthquake Engineering, Vancouver, BC, Canada, 2004

Ambraseys, N.: Earthquakes in the Mediterranean and Middle East, Cambridge University Press, New York, 2009.

Ambraseys, N. and Jackson, J.: Seismicity and Associated Strain of Central Greece between 1890 and 1988, Geophys. J. Int., 101, 663-708, 1990.

Aufgebauer, A., Panagiotopoulos, K., Wagner, B., Schäbitz, F., Viehberg, F. A., Vogel, H., Zanchetta, G., Sulpizio, R., Leng, M. J., and Damaschke, M.: Climate and environmental change in the Balkans over the last $17 \mathrm{ka}$ recorded in sediments, Quaternary Int., 274, 122-135, 2012.
Beck, C., Reyss, J.-L., Leclerc, F., Moreno, E., Feuillet, N., Barrier, L., Beauducel, F., Boudon, G., Clément, V., Deplus, C., Gallou, N., Lebrun, J.-F., Le Friant, A., Nercessian, A., Paterne, M., Pichot, T., and Vidal, C.: Identification of deep subaqueous coseismic scarps through specific coeval sedimentation in Lesser Antilles: implication for seismic hazard, Nat. Hazards Earth Syst. Sci., 12, 1755-1767, doi:10.5194/nhess-12-1755-2012, 2012.

Bordon, A., Peyron, O., Lézine, A.-M., Brewer, S., and Fouache, E.: Pollen-inferred Late-Glacial and Holocene climate in southern Balkans (Lake Maliq), Quaternary Int., 200, 19-30, 2009.

Burchfiel, B., Nakov, R., Dumurdzanov, N., Papanikolaou, D., Tzankov, T., Serafimovski, T., King, R., Kotzev, V., Todosov, A., and Nurce, B.: Evolution and Dynamics of the Cenozoic Tectonics of the South Balkan Extensional System, Geosphere, 4, 919-938, doi:10.1130/GES00169.1, 2008.

Caron, B., Sulpizio, R., Zanchetta, G., Siani, G., and Santacroce, R.: The Late Holocene to Pleistocene tephrostratigraphic record of Lake Ohrid (Albania), CR Acad. Sci., 342, 453-466, 2010.

Coltelli, M., Del Carlo, P., and Vezzoli, L.: Stratigraphic constrains for explosive activity in the past $100 \mathrm{ka}$ at Etna volcano, Italy, Int. J. Earth Sci., 89, 665-677, 2000.

Damaschke, M., Sulpizio, R., Zanchetta, G., Wagner, B., Böhm, A., Nowaczyk, N., Rethemeyer, J., and Hilgers, A.: Tephrostratigraphic studies on a sediment core from Lake Prespa in the Balkans, Clim. Past Discuss., 8, 4443-4492, doi:10.5194/cpd-84443-2012, 2012.

EMSC: Europen Mediterranean Seismological Centre, available at: www.emsc-csem.org, last access: 18 December 2012.

Gilli, A., Anselmetti, F. S., Ariztegui, D., Beres, M., McKenzie, J. A., and Markgraf, V.: Seismic stratigraphy, buried beach ridges and contourite drifts: the Late Quaternary history of the closed Lago Cardiel basin, Argentina ( $\left.49^{\circ} \mathrm{S}\right)$, Sedimentology, 52, 1-23, 2005.

Girardclos, S., Baster, I., Wildi, W., and Pugin, A.: Bottom-current and wind-pattern changes as indicated by Late-Glacial and Holocene sediments from western Lake Geneva (Switzerland), Eclogae Geol. Helv., 96, 39-48, 2003.

Girardclos, S., Schmidt, O. T., Sturm, M., Ariztegui, D., Pugin, A., and Anselmetti, F. S.: The 1996 AD delta collapse and large turbidite in Lake Brienz, Mar. Geol., 241, 137-154, 2007.

Hoffmann, N., Reicherter, K., Fernández-Steeger, T., and Grützner, C.: Evolution of ancient Lake Ohrid: a tectonic perspective, Biogeosciences, 7, 3377-3386, doi:10.5194/bg-7-3377-2010, 2010.

Kaniewski, D., Van Campo, E., Paulissen, E., Weiss, H., Bakker, J., Rossignol, I., and Van Lerberghe, K.: The medieval climate anomaly and the little Ice Age in coastal Syria inferred from pollen-derived palaeoclimatic patterns, Global Planet. Change, 78, 178-187, 2011.

Le Bas, M. J., Le Maitre, R. W., Streckeisen, A., and Zanettin, B.: A chemical classification of volcanic rocks based on the total alkali-silica diagram, J. Petrol., 27, 745-750, 1986.

Leng, M. J., Wagner, B., Aufgebauer, A., Panagiotopoulos, K., Vane, C., Snelling, A., Haidon, C., Woodley, E., Vogel, H., Zanchetta, G., Sulpizio, R., and Baneschi, I.: Understanding past climatic and hydrological variability in the Mediterranean from Lake Prespa sediment isotope and geochemical record over the last glacial cycle, Quaternary Sci. Rev., in press, 2012.

Lindhorst, K., Vogel, H., Krastel, S., Wagner, B., Hilgers, A., Zander, A., Schwenk, T., Wessels, M., and Daut, G.: Stratigraphic 
analysis of lake level fluctuations in Lake Ohrid: an integration of high resolution hydro-acoustic data and sediment cores, Biogeosciences, 7, 3531-3548, doi:10.5194/bg-7-3531-2010, 2010.

Lindhorst, K., Gruen, M., Krastel, S., and Schwenk, T.: Hydroacoustic Analysis of Mass Wasting Deposits in Lake Ohrid (FYR Macedonia/Albania), Submarine Mass Movements and Their Consequences, 245-253, 2012.

Muço, B., Vaccari, F., Panza, G., and Kuka, N.: Seismic zonation in Albania using a deterministic approach, Tectonophysics, 344, 277-288, 2002.

Reicherter, K., Hoffmann, N., Lindhorst, K., Krastel, S., FernandezSteeger, T., Grützner, C., and Wiatr, T.: Active Basins and Neotectonics: Morphotectonics of the Lake Ohrid Basin (FYROM and Albania), Z. Dtsch. Ges. Geowiss., 162, 217-234, 2011.

Reimer, P. J., Baillie, M. G. L., Bard, E., Bayliss, A., Beck, J. W., Blackwell, P. G., Ramsey, C. B., Buck, C. E., Burr, G. S., Edwards, R. L., Friedrich, M., Grootes, P. M., Guilderson, T. P., Hajdas, I., Heaton, T. J., Hogg, A. G., Hughen, K. A., Kaiser, K. F., Kromer, B., McCormac, F. G., Manning, S. W., Reimer, R. W., Richards, D. A., Southon, J. R., Talamo, S., Turney, C. S. M., van der Plicht, J., and Weyhenmeyer, C. E.: IntCal09 and Marine09 Radiocarbon Age Calibration Curves, 0-50,000 Years cal BP, Radiocarbon, 51, 1111-1150, 2009.

Rethemeyer, J., Fülöp, R. H., Höfle, S., Wacker, L., Heinze, S., Hajdas, I., Patt, U., König, S., Stapper, B., and Dewald, A.: Status report on sample preparation facilities for $14 \mathrm{C}$ analysis at the new CologneAMS center, Nucl. Instrum. Meth. B, 294, 168-172, doi:10.1016/j.nimb.2012.02.012, 2013.

Santacroce, R., Cioni, R., Marianelli, P., Sbrana, A., Sulpizio, R., Zanchetta, G., Donahue, D., and Joron, J.-L.: Age and whole rock-glass compositions of proximal pyroclastics from the major esplosive eruption of Somma-Vesuvius: a review as a tool for distal tephrostratigraphy, J. Volcanol. Geoth. Res., 177, 1-18, 2008.

Schnellmann, M., Anselmetti, F. S., Giardini, D., McKenzie, J. A., and Ward, S.: Prehistoric earthquake history revealed by lacustrine slump deposits, Geology, 30, 1131-1134, 2002.

Schnellmann, M., Anselmetti, F. S., Giardini, D., and McKenzie, J. A.: Mass movement-induced fold-and-thrust belt structures in unconsolidated sediments in Lake Lucerne (Switzerland), Sedimentology, 52, 271-289, 2005.

Schnellmann, M., Anselmetti, F. S., Giardini, D., and McKenzie, J. A.: 15,000 Years of massmovement history in Lake Lucerne: Implications for seismic and tsunami hazards, Eclogae Geol. Helv., 99, 409-428, 2006.

Stankovic, S.: The Balkan Lake Ohrid and its living world, Monographiae Biologicae IX, edited by: Junk, W., Den Haag, The Netherlands, 1960.

Stuiver, M. and Reimer, P. J.: Extended (super 14) C data base and revised CALIB 3.0 (super 14) C age calibration program, 1993.

Suhadolc, P., Sandron, D., Fitzko, F., and Costa, G.: Seismic Ground Motion Estimates for the M6.1 Earthquake of July 26, 1963 at Skopje, Republic of Macedonia, Acta Geod. Geophys. Hu., 39, 319-326, 2004.
Sulpizio, R., Zanchetta, G., D’Orazio, M., Vogel, H., and Wagner, B.: Tephrostratigraphy and tephrochronology of lakes Ohrid and Prespa, Balkans, Biogeosciences, 7, 3273-3288, doi:10.5194/bg7-3273-2010, 2010a.

Sulpizio, R., van Welden, A., Caron, B., and Zanchetta, G.: The Holocene tephrostratigraphic record of Lake Shkodra (Albania and Montenegro), J. Quaternary Sci., 25, 633-650, 2010b

Vogel, H., Wagner, B., Zanchetta, G., Sulpizio, R., and Rosén, P.: A paleoclimate record with tephrochronological age control for the last glacial-interglacial cycle from Lake Ohrid, Albania and Macedonia, J. Paleolimnol., 44, 295-310, 2010a.

Vogel, H., Zanchetta, G., Sulpizio, R., Wagner, B., and Nowaczyk, N.: A tephrostratigraphic record for the last glacial interglacial cycle from Lake Ohrid, Albania and Macedonia, J. Quaternary Sci., 25, 320-338, 2010b.

Vogel, H., Wessels, M., Albrecht, C., Stich, H.-B., and Wagner, B.: Spatial variability of recent sedimentation in Lake Ohrid (Albania/Macedonia), Biogeosciences, 7, 3333-3342, doi:10.5194/bg7-3333-2010, 2010c.

Wagner, B., Reicherter, K., Daut, G., Wessels, M., Matzinger, A., Schwalb, A., Spirkovski, Z., and Sanxhaku, M.: The potential of Lake Ohrid for long-term palaeoenvironmental reconstructions, Palaeogeogr. Palaeocl., 259, 341-356, 2008a.

Wagner, B., Sulpizio, R., Zanchetta, G., Wulf, S., Wessels, M., and Daut, G.: The last 40 ka tephrostratigraphic record of Lake Ohrid, Albania and Macedonia: a very distal archive for ash dispersal from Italian volcanoes, J. Volcanol. Geoth. Res., 177, 71-80, 2008b.

Wagner, B., Lotter, A. F., Nowaczyk, N., Reed, J. M., Schwalb, A., Sulpizio, R., Valsecchi, V., Wessels, M., and Zanchetta, G.: A 40,000-year record of environmental change from ancient Lake Ohrid (Albania and Macedonia), J. Paleolimnol., 41, 407-430, 2009.

Wagner, B., Vogel, H., Zanchetta, G., and Sulpizio, R.: Environmental change within the Balkan region during the past ca. $50 \mathrm{ka}$ recorded in the sediments from lakes Prespa and Ohrid, Biogeosciences, 7, 3187-3198, doi:10.5194/bg-7-3187-2010, 2010.

Wagner, B., Aufgebauer, A., Vogel, H., Zanchetta, G., Sulpizio, R., and Damaschke, M.: Late Pleistocene and Holocene contourite drift in Lake Prespa (Albania/F.Y.R. of Macedonia/Greece), Quaternary Int., 274, 259-272, 2012.

Zanchetta, G., Sulpizio, R., Roberts, N., Cioni, R., Eastwood, W. J., Siani, G., Caron, B., Paterne, M., and Santacroce, R.: Tephrostratigraphy, chronology and climatic events of the Mediterranean basin during the Holocene: an overview, Holocene, 21, 33-52, 2011.

Zanchetta, G., van Welden, A., Baneschi, I., Drysdale, R., Sadori, L., Roberts, N., Giardini, M., Beck, C., and Pascucci, V.: Multiproxy record for the last 4500 years from Lake Shkodra (Albania/Montenegro), J. Quaternary Sci., 27, 780-789, doi:10.1002/jqs.2563, 2012. 